\title{
Offshore Oil Pollution and Prevention Measures
}

\author{
Shasha Yang ${ }^{1, a}$, Kuanhong Xing ${ }^{2}$ and Yong Yang ${ }^{3}$ \\ ${ }^{1}$ Shaanxi Key Laboratory of Safety and Durability of Concrete Structures, XiJing University, Xi' an, Shaanxi, 710123, China \\ ${ }^{2}$ Baota Oil Production Plant, Shaanxi Yanchang Petroleum (Group) Co. Ltd., Yan'an, Shaanxi, 716000, China \\ ${ }^{3}$ Fuxian Oil Production Plant, Shaanxi Yanchang Petroleum (Group) Co. Ltd., Yan'an, Shaanx, 727500, China
}

\begin{abstract}
Oil pollution is one of the main pollutions of the marine environment. With the year-on-year increase of our country's oil imports and maritime transportation, our country's offshore oil pollution has become more and more serious, causing serious harm to the ocean and the nearshore environment. According to the current situation of marine oil pollution, the article outlines the current situation, sources, hazards of marine oil pollution, and the methods currently used to deal with and prevent marine oil pollution in physics, chemistry and biology.
\end{abstract}

\section{Introduction}

The ocean, forest and wetland are called the three major ecosystems of the earth, and they are an important barrier to maintain the global ecological balance. The ocean occupies $71 \%$ of the earth's surface area, and it occupies a very important position in the history of human social development, providing humans with rich mineral resources, space resources, production resources, etc. [1-3]. However, while the ocean provides us with a large amount of resources, it is also facing more and more severe pollution. The rational use and protection of marine resources is an urgent issue facing mankind[4-7]. Since the rapid economic take-off of China in the 1980s, environmental protection work, especially marine environmental protection and the harmless disposal of waste, have not been synchronized with economic development, so that the environmental quality of a considerable area of Chinese coastal waters has deteriorated, which has seriously hindered the coastal sustainable development of regional industrial and agricultural production and marine industry.

\section{Current status of marine oil pollution}

With the rapid development of world economic integration, energy represented by oil as a necessity for the development of various countries has become more and more tense. With the vigorous development of offshore oil exploitation and transportation, offshore oil pollution has become increasingly serious[8-14]. At present, marine oil pollution has brought serious damage to the marine ecological balance. Take the Penglai 19-3 oil field leakage incident (referred to as ConocoPhillips oil spill) that occurred in the Bohai Bay on June 4, 2011 as an example. Within a period of time, the polluted sea area has expanded from 16 square kilometers to nearly
6,200 square kilometers, bringing catastrophic damage to the local marine environment, the death of marine life, the destruction of habitats, the destruction of hatcheries, and so on. Moreover, after the oil spill, ConocoPhillips' attitude was very perfunctory, covering up information in the process of disseminating information, and at the same time falsifying and delaying the accident handling process in the handling of the accident. There are many loopholes and problems in marine oil pollution policy. In recent years, with the rapid development of the international shipping industry, the increasing intensity of offshore oil and gas exploration and development, and the increasing scale of coastal economies, the daily pollution and the marine oil pollution caused by emergencies have been increasing In addition to natural sources, petroleum and its refined products entering the marine environment mainly come from the following aspects.

\subsection{Oil extraction}

With the acceleration of the global industrialization process, the energy demand of human society has increased sharply. As one of the main energy sources, offshore oil and gas resources have rapidly expanded their mining scale. The number of offshore platforms, oil wells, and offshore oil transportation have increased sharply, and accidents have also increased. It is estimated that the world's oil production caused by leaks, blowouts and other accidents More than 1 million tons of petroleum pollutants are discharged every year.

\subsection{Sea transportation}

According to customs statistics, our country imported 1451.8 million tons of crude oil in 2006, a record high, and imported 36.38 million tons of refined oil. Total oil

\footnotetext{
${ }^{a}$ Corresponding author: 20190100@xijing.edu.cn
} 
imports rank third in the world, second only to the United States and Japan. In the most dynamic areas of our country's economic development, its fast-growing economy has produced a strong demand for oil. Our country's coastal waters have become intensive offshore oil exploration areas and crude oil seas transportation channels. The ballast water and washing water discharged from oil tanker operations usually contain $3 \%-5 \%$ oil. In the past, most of these oily wastewater was directly discharged into the sea, accounting for almost half of the total pollution of oil into the sea. In recent years, most oil tankers have recovered the oil in the waste water, so the pollution of the ocean has been reduced. However, investigations over the years still show that the oil pollution in the sea area of the marine oil transportation line is still relatively serious.

\subsection{Land source sewage discharge}

There are many large oil fields along the coast of our country. Onshore oil production and accidents can cause oil pollution to the ocean. In the foreseeable future, the coast will remain the center of economic gravity and the fastest economic development area in our country. With the continuous increase of the total economic volume and the acceleration of the process of industrialization, the total amount of pollutants entering the sea will still increase, especially the coastal areas with large numbers. Dumping of waste oil into the sea by industrial and mining enterprises such as oil refineries, petrochemical plants, and oil fields is the main source of pollution. According to the 2006 China Marine Environmental Quality Bulletin, only 609 land-sourced sewage outlets tested nationwide in 2006 discharged 100,000 tons of petroleum pollutants into the sea a year. This shows that the amount of petroleum that enters the sea every year in the country's seas is so large. At the same time, the petroleum pollutants dumped into the sea by waste and runoff shoes will volatilize into the atmospheric circulation, and follow the airflow to different areas for atmospheric deposition. It is estimated that about 5 million tons of petroleum pollutants are carried into the ocean by runoff each year in the world.

\section{The harm of marine oil pollution}

\subsection{Ecological hazards}

If the oil film caused by marine oil pollution is not cleaned up in time, it will float on the sea for a long time, just like adding a layer of plastic film in sea water and air, which affects the oxygen exchange between sea water and air, and also prevents sunlight from penetrating into the sea water. The photosynthesis of plankton declined, making it impossible to survive. The plankton is at the lowest end of the marine ecological food chain and is the main force of the primary productivity of marine organisms, accounting for about $90 \%$. Its reduction will affect the organisms in the upper layer of its food chain, and the influence of the chain relationship will eventually affect the organisms at the top of the marine food chain, resulting in the reduction of the entire marine life. If marine oil pollution occurs in areas with higher latitudes, the oil film on the ice surface will absorb more sunlight and increase the temperature of the ice surface. The melting ice layer will raise the sea level and cause global climate problems.

\subsection{Social harm}

Because oil pollution can inhibit the photosynthesis of marine organisms, reduce the dissolved oxygen content of seawater, destroy the physiological functions of organisms, and seriously endanger marine fishery resources. In recent years, our country's offshore fishery output has been declining year by year, and some precious fishes have been on the verge of extinction. The harm of hydrocarbons to the emerging marine aquaculture industry cannot be ignored. Fish, shrimp, and shellfish contaminated by hydrocarbons often lose their edible value because of their peculiar smell. After the water is polluted, the ponds cannot change water normally, which promotes the death of a large number of aquaculture objects. In addition, sea creatures such as wild shellfish and crabs in the tidal flats have also become extinct due to pollution. In sea areas with severe oil pollution, the probability of red tides has greatly increased. Although the mechanism of red tides is still inconclusive, the role of petroleum hydrocarbons cannot be ignored.

The oil floating in the ocean is easy to attach to fishing nets and other fishing gear, which is difficult to clean, which reduces the efficiency of fishing gear and increases fishing costs. Harm to the interests of coastal salt chemicals and seawater desalination plants and other enterprises. It is undoubtedly difficult to use contaminated seawater for salt drying plants, desalination plants and other companies that need seawater as raw materials, which will inevitably increase production costs significantly. Marine oil pollutants are very easy to stick to the shore and pollute the beaches and other attractive coastal entertainment venues, affect the image of coastal cities, and seriously affect the development of coastal tourism.

\section{Causes of marine oil pollution}

\subsection{Natural causes}

(1) The oil accumulated on the seabed seeps through the fractures of the formation fault. The degree of oil seepage is related to the intensity and frequency of crustal tectonic activities. According to statistics, the annual oil seepage into the ocean is estimated to be $(0.025 \sim 2.5) \times 10^{6} \mathrm{t}$.

(2) The river erodes the oil in the terrestrial sedimentary rock and then carries it into the ocean. According to statistics, the amount of "extractable" organic matter in the particulate organic matter carried by the river into the sea is about $10.6 \times 10^{6} \mathrm{t}$ per year in the world. 
(3) Hydrocarbons synthesized by terrestrial and marine biosynthesis are also one of the natural sources of petroleum hydrocarbons in the marine environment.

\subsection{Man-made reasons}

(1) Pollution from offshore oil exploration and development. It mainly includes oil spill, oil dispersant, drilling mud, fuel, ballast washing water and oil field production water, etc. It is usually a mixture of petroleum hydrocarbons, heavy metals, synthetic organics, and radioactive substances.

(2) Oil spills and sewage on offshore oil production platforms. With the development of offshore oil, oil spills from offshore oil production platforms around the world and oil pollution during operations, it is estimated that at least 95 thousand tons of oil are discharged into the ocean every year.

(3) Oil spills and sewage in marine transportation. Oil spills caused by accidents such as oil tanker collisions and reefs in maritime oil transportation, as well as operational sewage, ship repair operations, ballast water sewage, and so on. As a result, the oil that pollutes the ocean is about $(1.0 \sim 2.6) \times 10^{6}$ t per year.

\section{Countermeasures for prevention and control of marine oil pollution}

Alkanes are important components of crude oil, and their strong hydrophobicity is often not conducive to the rapid degradation of microorganisms in seawater, and pollution is difficult to eliminate by themselves. Therefore, to prevent and control oil pollution, we should adopt a two-pronged approach and treat both symptoms and root causes. On the one hand, we must take precautions, that is, through comprehensive protective measures to control pollution sources and prevent pollution from occurring. on the other hand, we must take measures, that is, we must promptly discover and deal with sudden marine oil pollution accidents. Various measures are adopted to reduce the content of petroleum hydrocarbons in the contaminated sea area as soon as possible, until the degree of pollution is lower than the self-purification capacity of the sea, and the pollution is eliminated step by step.The prevention and control of marine oil pollution includes physical treatment, chemical treatment and biological treatment, each of which has its own advantages and disadvantages (Table 1). Corresponding prevention and control countermeasures should be selected according to the pollution situation.

Table 1 Countermeasures for prevention and control of marine oil pollution and their advantages and disadvantages

\begin{tabular}{|c|l|l|l|}
\hline \multicolumn{2}{|c|}{$\begin{array}{c}\text { Prevention and } \\
\text { Control Methods of } \\
\text { Marine Oil Pollution }\end{array}$} & Advantages & Disadvantages \\
\hline $\begin{array}{c}\text { Physical } \\
\text { treatment }\end{array}$ & $\begin{array}{l}\text { Cleanup } \\
\text { ship }\end{array}$ & $\begin{array}{l}\text { There are many } \\
\text { types of } \\
\text { devices, which } \\
\text { can be flexibly }\end{array}$ & $\begin{array}{l}\text { The worse the } \\
\text { environmental } \\
\text { conditions, the } \\
\text { lower the }\end{array}$ \\
\hline
\end{tabular}

\begin{tabular}{|c|c|c|c|}
\hline & & $\begin{array}{l}\text { selected } \\
\text { according to the } \\
\text { oil spill } \\
\text { situation and } \\
\text { sea conditions }\end{array}$ & $\begin{array}{l}\text { working } \\
\text { efficiency of the } \\
\text { cleaning vessel, } \\
\text { or even nothing }\end{array}$ \\
\hline & $\begin{array}{l}\text { Oil } \\
\text { boom }\end{array}$ & $\begin{array}{l}\text { Good oil } \\
\text { retention ability, } \\
\text { strong wave } \\
\text { following, } \\
\text { resistance to } \\
\text { wind and } \\
\text { waves, } \\
\text { organisms are } \\
\text { not easy to } \\
\text { attach, tough } \\
\text { and firm, easy } \\
\text { to use and } \\
\text { maintain }\end{array}$ & $\begin{array}{l}\text { Difficult to use } \\
\text { in bad sea } \\
\text { conditions, } \\
\text { generally only } \\
\text { suitable for bays }\end{array}$ \\
\hline \multirow{3}{*}{$\begin{array}{l}\text { Chemical } \\
\text { treatment }\end{array}$} & $\begin{array}{l}\text { Emulsif } \\
\text { ying } \\
\text { and } \\
\text { dispersi } \\
\text { ng } \\
\text { agent }\end{array}$ & $\begin{array}{l}\text { Very convenient } \\
\text { to use, not } \\
\text { affected by } \\
\text { weather, sea } \\
\text { conditions and } \\
\text { other factors, it } \\
\text { is the first } \\
\text { choice under } \\
\text { harsh natural } \\
\text { conditions }\end{array}$ & $\begin{array}{l}\text { Only suitable } \\
\text { for the treatmen } \\
\text { of medium and } \\
\text { low } \\
\text { concentrations } \\
\text { of oil, and the } \\
\text { biological toxic } \\
\text { side effects of } \\
\text { ordinary oil } \\
\text { dispersants are } \\
\text { relatively } \\
\text { strong, which } \\
\text { may have } \\
\text { adverse effects } \\
\text { on the entire } \\
\text { marine food } \\
\text { chain after use }\end{array}$ \\
\hline & $\begin{array}{l}\text { Conden } \\
\text { sate }\end{array}$ & $\begin{array}{l}\text { Low toxicity } \\
\text { and recyclable, } \\
\text { not affected by } \\
\text { wind, waves } \\
\text { and currents, } \\
\text { and can } \\
\text { effectively } \\
\text { prevent the } \\
\text { spread of oil } \\
\text { film }\end{array}$ & $\begin{array}{l}\text { Some varieties } \\
\text { are more } \\
\text { expensive and } \\
\text { oil recovery } \\
\text { operations are } \\
\text { more } \\
\text { complicated }\end{array}$ \\
\hline & $\begin{array}{l}\text { Oil } \\
\text { catcher }\end{array}$ & $\begin{array}{l}\text { Low toxicity, } \\
\text { especially } \\
\text { suitable for the } \\
\text { removal of thin } \\
\text { oil layers in the } \\
\text { inland sea under } \\
\text { good weather } \\
\text { and sea } \\
\text { conditions }\end{array}$ & $\begin{array}{l}\text { Not suitable for } \\
\text { the removal of } \\
\text { thick oil layers }\end{array}$ \\
\hline $\begin{array}{l}\text { Biological } \\
\text { treatment }\end{array}$ & $\begin{array}{l}\text { Bacteria } \\
\text {, fungi, } \\
\text { yeasts, } \\
\text { molds, } \\
\text { etc. }\end{array}$ & $\begin{array}{l}\text { Fast, non-toxic } \\
\text { and low cost }\end{array}$ & $\begin{array}{l}\text { When using } \\
\text { chemicals to } \\
\text { remove oil, the } \\
\text { growth and } \\
\text { reproduction of } \\
\text { microorganisms } \\
\text { will be inhibited } \\
\text { by chemicals }\end{array}$ \\
\hline
\end{tabular}

\subsection{Physical treatment method}

At present, physical methods and mechanical devices are used to eliminate oil pollution on the sea surface and 
coastal zone. The method has the highest efficiency, but it is less effective for thin oil layers and emulsified oil with a thickness of less than $0.3 \mathrm{~mm}$.

\subsection{Chemical treatment method}

Chemical treatment methods include traditional chemical treatment methods and modern chemical treatment methods. The traditional chemical treatment method is the combustion method, which removes a large amount of floating oil in a short time through combustion, with low cost and good effect. However, the disadvantage of this method is that incomplete combustion of oil slick will release dense smoke, produce a large amount of secondary pollutants such as aromatics, and pollute the ocean and atmosphere. Another shortcoming of this method is that it is more dangerous to use near shore, so this method is mostly used for offshore oil pollution treatment. The modern chemical treatment method refers to the use of chemical treatment agents to change the existing form of oil slick in the sea, so that the crude oil may be condensed into oil lumps and be recycling by mechanical devices, or emulsifying and dispersing in seawater for natural degradation and elimination. This method is mostly used for large-scale oil removal operations under severe sea conditions and other weather conditions.

\subsection{Biological treatment method}

There are some oleaginous microorganisms that can degrade petroleum hydrocarbons in the natural environment, such as bacteria, fungi, yeasts, molds, etc., and they are also one of the natural fate of hydrocarbon pollutants. In the ocean, bacteria and yeasts are the main degradation of hydrocarbons. By the so-called biological treatment method is also known as the bioremediation method, which is a method of artificially selecting, cultivating and even improving these oleaginous microorganisms, and then put them into the contaminated sea area for artificial petroleum hydrocarbon biodegradation. It has been found that more than 700 species of fungi can participate in the degradation of petroleum hydrocarbons. The bioremediation method is considered to be the most economical, most thorough and effective means of restoration for the treatment of marine petroleum hydrocarbon pollution. The degradability and degradation rate of marine microorganisms are related to the movement, distribution, morphology and dissolved oxygen in the system. The advantages of using the biodegradation method are that it is rapid, non-toxic and low-cost. but the current problem is that when using chemicals to remove oil, the growth and reproduction of microorganisms will be inhibited by chemicals, and the other is to choose appropriate Strains to reduce the impact on the ecological system of the polluted sea area.

\section{Conclusion}

Petroleum pollutants are different from conventional pollutants. Once they pollute the waters and food chain, they are not easily destroyed after entering the organism, and they still maintain their persistence, mobility, accumulation and high toxicity. They will eventually endanger the organism and appear carcinogenic, mutagenic and teratogenic effects, which seriously endanger human health, therefore, it must be highly valued by the whole society. As a large number of marine pollutants, petroleum hydrocarbons are more toxic and have a long-term pollution effect, and their harm has spread all over the world. We should minimize the pollution of oil to the marine environment, especially the coastal waters, maintain a good marine ecological environment and embark on a sustainable development path that protects and utilizes the ocean.

\section{References}

1. Li Shuwen. Environmental Philosophy-A Study of Environmental Issues in the Philosophical Perspective[M]. Beijing: Communication University of China Press, 2010 edition.

2. Dong Xiaolin. The Construction of Contemporary China's Environmental Sociology[M]. Beijing: Social Sciences Literature Press, 2010 edition.

3. He Weidong, Sustainable Development of Environmental Industry and Innovation of China's Environmental Laws and Policies[M]. Shanghai: Shanghai Science and Technology Education Press, 2005 edition.

4. $\mathrm{Gu}$ Haibo. Environmental technology policy innovation based on the concept of sustainable development[M]. Liaoning: Northeastern University Press, 2004 edition.

5. Gao Zhenhui, Yang Jianqiang, Wang Peigang. Theories, methods and case studies of marine oil spill ecological damage assessment [M]. Beijing: Ocean Press, 2007 edition.

6. Wang Jinnan, Zou Shoumin, Hong Yaxiong, China Environmental Policy[M]. Beijing: China Environmental Science Press, 2006 Year edition.

7. Xia Guang. Environmental Policy InnovationEconomic Analysis of Environmental Policy[M]. Beijing: China Environmental Science Press, 2001 edition.

8. Li Kang. Environmental Policy[M]. Beijing: Tsinghua University Press, 2000 edition.

9. Li Jinhua, China Sustainable Development Accounting System (SSDA)[M]. Beijing: Social Sciences Literature Press, 2000 edition.

10. Gu Xinyue, New Trends in U.S. Ocean Policy[J]. Global Science and Technology Economy Hope, 1999(1).

11. Jin Yongming.On the East China Sea Issues and Joint Development[J].Social Sciences, 2007(6). 
12. Jin Yongming.New trends in Japan's oceans and their enlightenment to our country[J].Law Science, 2007(5).

13. Su Yongxiang et al. Ethical analysis of the construction of a new socialist countryside[J]. Journal of Sun Yat-sen University, 2006(11). 